\title{
Novel $\mu_{3}-0 x o$ complexes prepared from $\mathrm{Cp} * \mathrm{Zr}\left(\mathrm{BH}_{3} \mathrm{R}\right)_{3}\left(\mathrm{R}=\mathrm{H}, \mathrm{CH}_{3}\right)$ and $B\left(C_{6} F_{5}\right)_{3}$ in diethyl ether $\dagger$
}

\author{
Fu-Chen Liu, ${ }^{* a}$ Chien-Chan Yang, ${ }^{a}$ Shou-Chon Chen, ${ }^{a}$ Gene-Hsian Lee ${ }^{b}$ and Shie-Ming Peng ${ }^{b}$ \\ Received 3rd January 2008, Accepted 4th April 2008 \\ First published as an Advance Article on the web 27th May 2008 \\ DOI: 10.1039/b719863a
}

From the reactions of $\mathrm{Cp}^{*} \mathrm{ZrCl}_{3}$ with 3 equiv. of $\mathrm{LiBH}_{3} \mathrm{R}\left(\mathrm{R}=\mathrm{CH}_{3}, \mathrm{Ph}\right)$, the organotrihydroborate complexes, $\mathrm{Cp} * \mathrm{Zr}\left(\mathrm{BH}_{3} \mathrm{CH}_{3}\right)_{3}, \mathbf{1}$, and $\mathrm{Cp}^{*} \mathrm{Zr}\left(\mathrm{BH}_{3} \mathrm{Ph}\right)_{3}$, 2, were isolated. One of the $\mathrm{Zr}-\mathrm{H}-\mathrm{B}$ bonding interactions in $\mathbf{2}$ could be described as an intermediate case between the bidentate and tridentate modes. Reactions of 1 and $\mathrm{Cp} * \mathrm{Zr}\left(\mathrm{BH}_{4}\right)_{3}, \mathbf{3}$, with Lewis acid $\mathrm{B}\left(\mathrm{C}_{6} \mathrm{~F}_{5}\right)_{3}$ in diethyl ether produced the novel 14-electron ionic compounds $\left[\left(\mu_{3}-\mathrm{O}\right)\left(\mu_{2}-\mathrm{OC}_{2} \mathrm{H}_{5}\right)_{3}\left\{\left(\mathrm{Cp}^{*} \mathrm{Zr}\left(\mathrm{OC}_{2} \mathrm{H}_{5}\right)\right)_{2}\left(\mathrm{BCH}_{3}\right)\right\}\right]\left[\mathrm{HB}\left(\mathrm{C}_{6} \mathrm{~F}_{5}\right)_{3}\right], 4$, and $\left[\left(\mu_{3}-\mathrm{O}\right)\left(\mu_{2}-\mathrm{OC}_{2} \mathrm{H}_{5}\right)_{3}\left\{\left(\mathrm{Cp}^{*} \mathrm{Zr}\left(\mathrm{OC}_{2} \mathrm{H}_{5}\right)\right)_{2}\left(\mathrm{BOC}_{2} \mathrm{H}_{5}\right)\right\}\right]\left[\mathrm{HB}\left(\mathrm{C}_{6} \mathrm{~F}_{5}\right)_{3}\right], \mathbf{5}$, respectively. These two unique compounds resulted from a sequential cleavage of $\mathrm{Zr}-\mathrm{H}-\mathrm{B}$ bonds of $\mathbf{1}$ and $\mathbf{3}$ and $\mathrm{C}-\mathrm{O}$ bonds of ether followed by the formation of $\mathrm{O}-\mathrm{B}$ bonds. The solid state single crystal X-ray analyses revealed that both compounds have similar structures. A $\mu_{3}$-oxygen bridges two zirconiums and a boron atom. The latter three atoms are further connected by three $\mu_{2}$-bridging ethoxy groups giving rise to three four-membered metallacycles within the structure of each cation.

\section{Introduction}

Group 4 transition metal hydroborate complexes are of interest due to their fluxional behavior, the nature of the bonding interaction between the $\mathrm{BH}_{4}{ }^{-}$ligand and a metal, ${ }^{1,2}$ their ability to function as reducing agents ${ }^{3}$ and precursors in the preparation of hydride complexes ${ }^{4}$ as well as their applications in the chemical vapour deposition (CVD) of $\mathrm{ZrB}_{2}$ and $\mathrm{HfB}_{2}$ films ${ }^{5}$ and in hydroboration as catalysts. ${ }^{6}$ The terahydroborate zirconocene complexes have been studied since the 1960 's. ${ }^{1}$ Recently the related Group 4 organohydroborate complexes have also been reported..$^{7-13}$ Many zirconocene-based organohydroborate compounds have been prepared and studied by Shore and co-workers ${ }^{7-10}$ as well as by our group. ${ }^{12,13}$ These organohydroborate compounds display interesting dynamic properties ${ }^{8}$ and bonding interactions between the organohydroborate ligand and the metal. ${ }^{9}$ Compared with the zirconocene compounds, the half-sandwich zirconocene compounds possess a face that is more open to attack and has more coordination sites available, which may result in interesting bonding interactions and different chemical behavior. However, the related organohydroborate complexes are not well studied. To our knowledge, only a handful of examples of the half-sandwich zirconocene hydroborate and organohydroborate complexes have been reported..$^{10,14,15}$ Thus, we are interested in exploration of the half-zirconocene organohydroborate chemistry. Here we would like to report the results of our recent study on the preparation of the half-sandwich zirconocene organotrihydroborate compounds and their reaction with a Lewis acid $\mathrm{B}\left(\mathrm{C}_{6} \mathrm{~F}_{5}\right)_{3}$.

aDepartment of Chemistry, National Dong Hwa University, Hualien, 974, Taiwan, ROC. E-mail: fcliu@mail.ndhu.edu.tw; Fax: +886 38633570; Tel: +88638633601

${ }^{b}$ Department of Chemistry, National Taiwan University, Taipei, 106, Taiwan, $R O C$

$\dagger$ Electronic supplementary information (ESI) available: Crystallographic data. CCDC reference numbers 672315-672319. For ESI and crystallographic data in CIF or other electronic format see DOI: $10.1039 / \mathrm{b} 719863 \mathrm{a}$

\section{Results and discussion}

Formation and spectroscopic study of $\mathrm{Cp} * \mathrm{Zr}\left(\mathrm{BH}_{3} \mathrm{CH}_{3}\right)_{3}, 1$, $\mathrm{Cp} * \mathrm{Zr}\left(\mathrm{BH}_{3} \mathrm{Ph}\right)_{3}, 2,\left[\left(\mu_{3}-\mathrm{O}\right)\left(\mu_{2}-\mathrm{OC}_{2} \mathrm{H}_{5}\right)_{3}\left\{\left(\mathrm{Cp}^{*} \mathrm{Zr}\left(\mathrm{OC}_{2} \mathrm{H}_{5}\right)\right)_{2}-\right.\right.$ $\left.\left.\left(\mathrm{BCH}_{3}\right)\right\}\right]\left[\mathrm{HB}\left(\mathrm{C}_{6} \mathrm{~F}_{5}\right)_{3}\right], 4$, and $\left[\left(\mu_{3}-\mathrm{O}\right)\left(\mu_{2}-\mathrm{OC}_{2} \mathrm{H}_{5}\right)_{3}\left\{\left(\mathrm{Cp}^{*} \mathrm{Zr}-\right.\right.\right.$ $\left.\left.\left.\left(\mathrm{OC}_{2} \mathrm{H}_{5}\right)\right)_{2}\left(\mathrm{BOC}_{2} \mathrm{H}_{5}\right)\right\}\right]\left[\mathrm{HB}\left(\mathrm{C}_{6} \mathrm{~F}_{5}\right)_{3}\right], 5$

Compounds $\mathrm{Cp} * \mathrm{Zr}\left(\mathrm{BH}_{3} \mathrm{CH}_{3}\right)_{3}, \mathbf{1}$, and $\mathrm{Cp} * \mathrm{Zr}\left(\mathrm{BH}_{3} \mathrm{Ph}\right)_{3}, 2$ were prepared from the reaction of $\mathrm{Cp}^{*} \mathrm{ZrCl}_{3}$ with 3 equiv. of $\mathrm{LiBH}_{3} \mathrm{R}$ $\left(\mathrm{R}=\mathrm{CH}_{3}, \mathrm{Ph}\right)$ in diethyl ether, as shown in eqn (1).

$$
\begin{gathered}
\mathrm{Cp}^{*} \mathrm{ZrCl}_{3}+3 \mathrm{LiBH}_{3} \mathrm{R} \underset{\left(\mathrm{R}=\mathrm{CH}_{3}, \mathrm{Ph}\right)}{\stackrel{\text { ether }}{\longrightarrow}} \mathrm{Cp} * \mathrm{Zr}\left(\mathrm{BH}_{3} \mathrm{R}\right)_{3}
\end{gathered}
$$

Both compounds were crystallized from ether solution at $-35^{\circ} \mathrm{C}$. While compound $\mathbf{1}$ is very soluble in ether, compound 2 has a low solubility in this solvent. Their ${ }^{11} \mathrm{~B}$ NMR spectra display a broad signal at $-5.50 \mathrm{ppm}$ for $\mathbf{1}$ and a broad quartet $\left(J_{\mathrm{B}-\mathrm{H}}=69 \mathrm{~Hz}\right)$ at $-4.32 \mathrm{ppm}$ for $\mathbf{2}$. These resonances are downfield with respect to those of the free anions $\left(\mathrm{LiBH}_{3} \mathrm{Ph}\right.$ : $-26.5 \mathrm{ppm}$; $\mathrm{LiBH}_{3} \mathrm{CH}_{3}$ : $\left.-30.9 \mathrm{ppm}\right){ }^{12,16}$ In the proton NMR spectra, the BH hydrogens of $\mathbf{1}$ and $\mathbf{2}$ appear as broad quartets at 1.37 and $2.28 \mathrm{ppm}$, respectively.

Compounds $\left[\left(\mu_{3}-\mathrm{O}\right)\left(\mu_{2}-\mathrm{OC}_{2} \mathrm{H}_{5}\right)_{3}\left\{\left(\mathrm{Cp}^{*} \mathrm{Zr}\left(\mathrm{OC}_{2} \mathrm{H}_{5}\right)\right)_{2}\left(\mathrm{BCH}_{3}\right)\right\}\right]-$ $\left[\mathrm{HB}\left(\mathrm{C}_{6} \mathrm{~F}_{5}\right)_{3}\right], \quad 4$, and $\left[\left(\mu_{3}-\mathrm{O}\right)\left(\mu_{2}-\mathrm{OC}_{2} \mathrm{H}_{5}\right)_{3}\left\{\left(\mathrm{Cp}^{*} \mathrm{Zr}\left(\mathrm{OC}_{2} \mathrm{H}_{5}\right)\right)_{2}\right.\right.$ $\left.\left.\left(\mathrm{BOC}_{2} \mathrm{H}_{5}\right)\right\}\right]\left[\mathrm{HB}\left(\mathrm{C}_{6} \mathrm{~F}_{5}\right)_{3}\right]$, 5, were prepared from the reaction of 1 and $\mathrm{Cp} * \mathrm{Zr}\left(\mathrm{BH}_{4}\right)_{3},{ }^{15}$ 3, respectively, with $\mathrm{B}\left(\mathrm{C}_{6} \mathrm{~F}_{5}\right)_{3}$ in ether according to eqn (2),

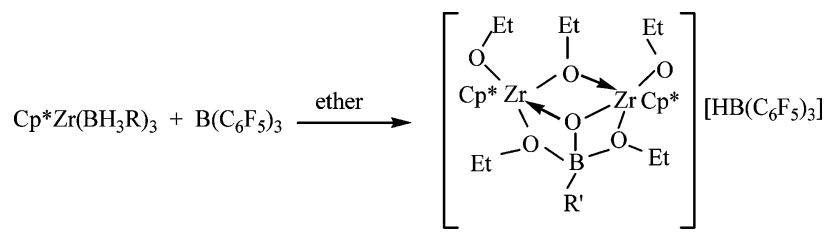

$\left(\mathrm{R}=\mathrm{CH}_{3}, \mathrm{R}^{\prime}=\mathrm{CH}_{3}(\mathbf{4}) ; \mathrm{R}=\mathrm{H}, \mathrm{R}^{\prime}=\mathrm{OC}_{2} \mathrm{H}_{5}(\mathbf{5})\right)$ 
and isolated from a ether-hexane two-layered system. Crystals of $\mathbf{4}$ and $\mathbf{5}$ are only slightly soluble in ether while they decompose in other commonly used solvents. In fact, decomposition of $\mathbf{4}$ is so fast that its resonances could not be identified in the proton NMR spectrum. Decomposition of $\mathbf{5}$ in $\mathrm{d}_{8}$-toluene is slower, and by comparing the intensity of the signals of the time-elapsed spectra it was possible to identify its original ${ }^{1} \mathrm{H}$ NMR signals. Although four different bonding environments for an ethoxy group can be found in $\mathbf{5}$, they cannot be distinguished in its proton NMR spectrum, which displays only one set of signals for all of them. The $\mathrm{CH}_{2}$ protons appear at $3.19 \mathrm{ppm}\left(\mathrm{q}, J_{\mathrm{H}-\mathrm{H}}=\right.$ $7.0 \mathrm{~Hz})$ and the $\mathrm{CH}_{3}$ protons appear at $0.98 \mathrm{ppm}\left(\mathrm{t}, J_{\mathrm{H}-\mathrm{H}}=\right.$ $7.0 \mathrm{~Hz})$. In the ${ }^{13} \mathrm{C}$ NMR the ethoxy methylene and methyl signals appear at 65.55 and $14.61 \mathrm{ppm}$, respectively. The hydride signal of the anion $\left[\mathrm{HB}\left(\mathrm{C}_{6} \mathrm{~F}_{5}\right)_{3}\right]^{-}$is not observed in the proton NMR spectrum, possibly due to its broadness. The instance of terminal and bridging alkoxide group proton chemical shifts being the same has been observed previously. ${ }^{10,17}$ Two boron signals are observed for each compound in a freshly prepared solution. A doublet signal at $-26 \mathrm{ppm}\left(\mathrm{d}, J_{\mathrm{B}-\mathrm{H}}=93 \mathrm{~Hz}\right)$ in each spectrum is assigned to the anion $\left[\mathrm{HB}\left(\mathrm{C}_{6} \mathrm{~F}_{5}\right)_{3}\right]^{-}$. The cation boron signals appear as singlets at $30.5 \mathrm{ppm}$ for $\mathbf{4}$ and $17.6 \mathrm{ppm}$ for $\mathbf{5}$. Unlike the proton NMR spectra, the boron NMR spectra do not provide any information with regard to the decomposition of these compounds in solution. It is possible that decomposition occurs at the electron deficient metal center, and the boron atom of the anion and the four-coordinated boron atom of the cation are not affected at the beginning of decomposition.

The reaction of $\mathrm{Cp} * \mathrm{Zr}\left(\mathrm{BH}_{3} \mathrm{Ph}\right)_{3}$ with $\mathrm{B}\left(\mathrm{C}_{6} \mathrm{~F}_{5}\right)_{3}$ in diethyl ether was also studied. The boron NMR spectrum of the product mixture displayed three boron signals, with two major ones appearing at $27.38(\mathrm{~s})$ and $-26.19 \mathrm{ppm}\left(\mathrm{d}, J_{\mathrm{B}-\mathrm{H}}=91 \mathrm{~Hz}\right)$. This result suggested the formation of a product similar to compound 4. However, we have not met with success in isolation of this product.

Shore and co-workers ${ }^{10}$ have prepared compound $\left[\left(\mu_{2}-\right.\right.$ $\left.\left.\mathrm{OC}_{2} \mathrm{H}_{5}\right)\left\{\mathrm{CpZr}\left(\mathrm{OC}_{2} \mathrm{H}_{5}\right)\left(\mathrm{OC}_{4} \mathrm{H}_{10}\right)\right\}\right]_{2}\left[\mathrm{HB}\left(\mathrm{C}_{6} \mathrm{~F}_{5}\right)_{3}\right]_{2}$ from the reaction of $\mathrm{CpZr}\left\{\mathrm{BH}_{2}\left(\mathrm{C}_{5} \mathrm{H}_{10}\right)\right\}_{3}$ with $\mathrm{B}\left(\mathrm{C}_{6} \mathrm{~F}_{5}\right)_{3}$ in diethyl ether. Formation of $\mathbf{4}$ and $\mathbf{5}$ may follow a similar pathway producing an intermediate $\left[\left(\mu_{2}-\mathrm{OC}_{2} \mathrm{H}_{5}\right)\left\{\mathrm{Cp} * \mathrm{Zr}\left(\mathrm{OC}_{2} \mathrm{H}_{5}\right)\left(\mathrm{OC}_{4} \mathrm{H}_{10}\right)\right\}\right]_{2}\left[\mathrm{HB}\left(\mathrm{C}_{6} \mathrm{~F}_{5}\right)_{3}\right]_{2}$, which is an analog of Shore's compound. It is possible that this intermediate reacts further by coordination of a bridging oxygen to $\mathrm{BH}_{3}$ formed in previous steps followed by a hydride transfer from $\left[\mathrm{HB}\left(\mathrm{C}_{6} \mathrm{~F}_{5}\right)_{3}\right]^{-}$to the ethyl group giving rise to an intermediate $\left[\left(\mu_{2}-\right.\right.$ $\left.\left.\mathrm{OC}_{2} \mathrm{H}_{5}\right)\left(\mu_{2}-\mathrm{OBH}_{3}\right)\left\{\mathrm{Cp}^{*} \mathrm{Zr}\left(\mathrm{OC}_{2} \mathrm{H}_{5}\right)\left(\mathrm{OC}_{4} \mathrm{H}_{10}\right)\right\}_{2}\right]\left[\mathrm{HB}\left(\mathrm{C}_{6} \mathrm{~F}_{5}\right)_{3}\right]$. Repeated attacks by the coordinated $\mathrm{BH}_{3}$ moiety on the ethyl groups of coordinated ether molecules resulting in bond formation between the oxygen and boron atoms will produce $\left[\left(\mu_{3}-\mathrm{O}\right)\left(\mu_{2}-\mathrm{OC}_{2} \mathrm{H}_{5}\right)_{3}\left\{\left(\mathrm{Cp} * \mathrm{Zr}\left(\mathrm{OC}_{2} \mathrm{H}_{5}\right)\right)_{2}(\mathrm{BH})\right\}\right]\left[\mathrm{HB}\left(\mathrm{C}_{6} \mathrm{~F}_{5}\right)_{3}\right]$. Reaction of the last $\mathrm{BH}$ hydrogen of this intermediate with ether will furnish final product $\mathbf{5}$. When the boron source is $\left(\mathrm{BH}_{2} \mathrm{CH}_{3}\right)_{2}$, which has only two $\mathrm{BH}$ hydrogens available, further reaction of the intermediate $\left[\left(\mu_{2}-\mathrm{OC}_{2} \mathrm{H}_{5}\right)\{\mathrm{Cp} * \mathrm{Zr}\right.$ $\left.\left(\mathrm{OC}_{2} \mathrm{H}_{5}\right)\left(\mathrm{OC}_{4} \mathrm{H}_{10}\right)\right\}_{2}\left[\mathrm{HB}\left(\mathrm{C}_{6} \mathrm{~F}_{5}\right)_{3}\right]_{2}$ will produce compound 4 . The fact that these reactions do not stop at the formation of $\left[\left(\mu_{2}-\mathrm{OC}_{2} \mathrm{H}_{5}\right)\left\{\mathrm{Cp} * \mathrm{Zr}\left(\mathrm{OC}_{2} \mathrm{H}_{5}\right)\left(\mathrm{OC}_{4} \mathrm{H}_{10}\right)\right\}\right]_{2}\left[\mathrm{HB}\left(\mathrm{C}_{6} \mathrm{~F}_{5}\right)_{3}\right]_{2}$ may be attributed to a better electron donor ability of the $\mathrm{Cp}^{*}$ ligand, and/or the nature of the hydroboranes. Studies of the factors affecting the formation of $\mathbf{4}$ and $\mathbf{5}$ are in progress.

\section{Molecular structures of $1,2,3,4$, and 5}

The structure of $\mathrm{Cp} * \mathrm{Zr}\left(\mathrm{BH}_{4}\right)_{3}$ (compound 3 first synthesized by Wolczanski and Bercaw ${ }^{15}$ ) is included for comparison. The molecular structures of 1-5 were determined by single-crystal Xray diffraction analysis. Crystallographic data and selected bond distances and bond angles are given in Tables 1-4. The molecular structures of 2, 4, and 5 are shown in Fig. 1-3. The molecular structures of $\mathbf{1}$ and $\mathbf{3}$ are similar to that of $\mathbf{2}$ and they are included in the ESI. $\dagger$

The coordination geometry of zirconium atoms in the molecular structures of $\mathbf{1 - 3}$ can be described best as a distorted tetrahedron. At the corners of each tetrahedron are the center of a $\mathrm{Cp}^{*}$ ring and three boron atoms connected to a zirconium atom through bridging hydrogens. The metal-boron distance has been used as a criterion for determining the bonding mode between the metal and the hydroborate ligand. ${ }^{1,18}$ Hedberg et al. estimated the expected $\mathrm{Zr}-\mathrm{B}$ distances for a bidentate mode to be in the range 2.39-2.59 $\AA$ and for a tridentate mode to be in the range $2.28-2.40 \AA{ }^{14}$ The average $\mathrm{Zr}-\mathrm{B}$ distances for $\mathbf{1 - 3}$ increase in the order $\mathbf{3}<\mathbf{1}<\mathbf{2}$, which is consistent with the bulkiness of the fourth substituent

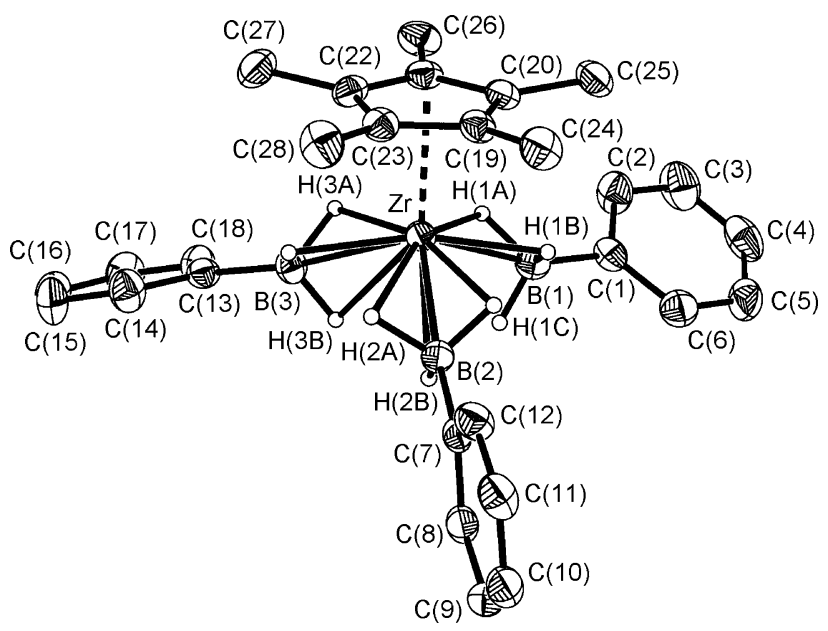

Fig. 1 Molecular structure of $\mathrm{Cp} * \mathrm{Zr}\left(\mathrm{BH}_{3} \mathrm{Ph}\right)_{3}, 2$, showing $50 \%$ probability thermal ellipsoids.

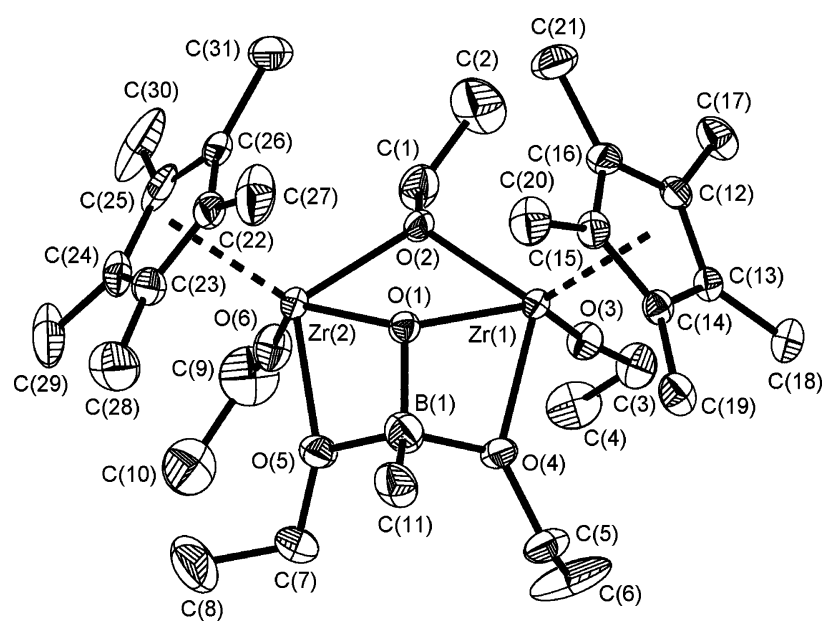

Fig. 2 Molecular structure of the cation in $\left[\left(\mu_{3}-\mathrm{O}\right)\left(\mu_{2}-\right.\right.$ $\left.\left.\mathrm{OC}_{2} \mathrm{H}_{5}\right)_{3}\left\{\left(\mathrm{Cp}^{*} \mathrm{Zr}\left(\mathrm{OC}_{2} \mathrm{H}_{5}\right)\right)_{2}\left(\mathrm{BCH}_{3}\right)\right\}\right]\left[\mathrm{HB}\left(\mathrm{C}_{6} \mathrm{~F}_{5}\right)_{3}\right], \quad \mathbf{4}, \quad$ showing $30 \%$ probability thermal ellipsoids. 
Table 1 Crystal data and structure refinement for $\mathrm{Cp}^{*} \mathrm{Zr}\left(\mathrm{BH}_{3} \mathrm{CH}_{3}\right)_{3}, \mathbf{1}, \mathrm{Cp} * \mathrm{Zr}\left(\mathrm{BH}_{3} \mathrm{Ph}\right)_{3}, \mathbf{2}$, and $\mathrm{Cp} * \mathrm{Zr}\left(\mathrm{BH}_{4}\right)_{3}, 3$

\begin{tabular}{|c|c|c|c|}
\hline Empirical formula & $\mathrm{C}_{13} \mathrm{H}_{33} \mathrm{~B}_{3} \mathrm{Zr}$ & $\mathrm{C}_{28} \mathrm{H}_{39} \mathrm{~B}_{3} \mathrm{Zr}$ & $\mathrm{C}_{10} \mathrm{H}_{27} \mathrm{~B}_{3} \mathrm{Zr}$ \\
\hline$M$ & 313.04 & 499.24 & 270.97 \\
\hline$T / \mathrm{K}$ & $150(2)$ & $150(2)$ & $150(1)$ \\
\hline Crystal system & Tetragonal & Monoclinic & Triclinic \\
\hline Space group & $P 4(3)$ & $P 2(1) / n$ & $P \overline{1}$ \\
\hline$a / \AA$ & $7.8250(3)$ & $8.8868(1)$ & $7.0619(8)$ \\
\hline$b / \AA ̊$ & $7.8250(3)$ & $14.7203(2)$ & $8.4186(9)$ \\
\hline$c / \AA ̊$ & $28.7350(11)$ & $20.4718(3)$ & $13.4982(15)$ \\
\hline$a /^{\circ}$ & & & $84.077(2)$ \\
\hline$\beta /^{\circ}$ & & $91.1669(5)$ & $88.589(2)$ \\
\hline$\gamma /{ }^{\circ}$ & & & $66.427(2)$ \\
\hline$V / \AA^{3}$ & $1759.46(12)$ & $2677.49(6)$ & $731.47(14)$ \\
\hline$Z$ & 4 & 4 & 2 \\
\hline$\rho_{\text {calcd }} / \mathrm{g} \mathrm{cm}^{-3}$ & 1.182 & 1.238 & 1.230 \\
\hline Crystal size/mm & $0.30 \times 0.30 \times 0.30$ & $0.25 \times 0.25 \times 0.20$ & $0.20 \times 0.20 \times 0.10$ \\
\hline Radiation $(\lambda / \AA ̊)$ & Mo-K $\alpha(0.71073)$ & Mo-K $\alpha(0.71073)$ & Mo-K $\alpha(0.71073)$ \\
\hline$\theta$ limits $/^{\circ}$ & $2.60-27.50$ & $1.70-27.50$ & $1.52-27.50$ \\
\hline \multirow[t]{3}{*}{ Index ranges } & $-10 \leq h \leq 10$ & $-11 \leq h \leq 11$ & $-9 \leq h \leq 9$ \\
\hline & $-10 \leq k \leq 10$ & $-19 \leq k \leq 18$ & $-10 \leq k \leq 10$ \\
\hline & $-37 \leq l \leq 37$ & $-26 \leq l \leq 26$ & $-17 \leq l \leq 17$ \\
\hline Reflns collected & 17156 & 20179 & 9665 \\
\hline Unique reflns & 4028 & 6152 & 3345 \\
\hline$F(000)$ & 664 & 1048 & 284 \\
\hline Completeness to $\theta(\%)$ & 100.0 & 100.0 & 99.7 \\
\hline$\mu / \mathrm{mm}^{-1}$ & 0.605 & 0.424 & 0.717 \\
\hline Max., min. transm. & $0.8394,0.8394$ & $0.940,0.867$ & $0.9318,0.8699$ \\
\hline Data/restraints/params & $4028 / 1 / 181$ & $6152 / 0 / 326$ & $3345 / 0 / 175$ \\
\hline$R_{1}{ }^{a}[I>2.0 \sigma(I)]$ & 0.0257 & 0.0410 & 0.0364 \\
\hline$w R_{2}^{b}$ (all data) & 0.0643 & 0.1152 & 0.0873 \\
\hline$R_{\text {int }}$ & 0.0366 & 0.0712 & 0.0351 \\
\hline GOF on $F^{2}$ & 1.052 & 1.077 & 1.155 \\
\hline
\end{tabular}

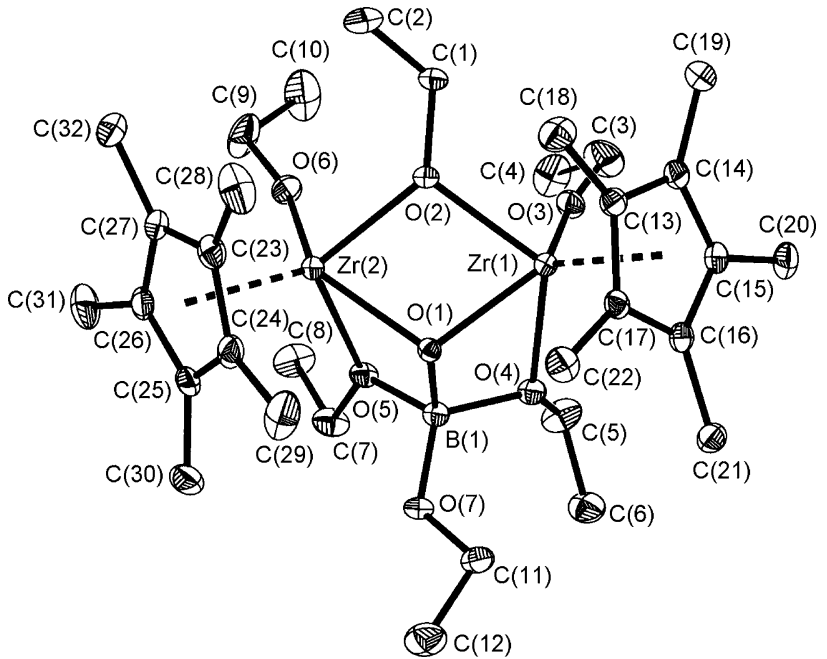

Fig. 3 Molecular structure of the cation in $\left[\left(\mu_{3}-\mathrm{O}\right)\left(\mu_{2}-\right.\right.$ $\left.\left.\mathrm{OC}_{2} \mathrm{H}_{5}\right)_{3}\left\{\left(\mathrm{Cp} * \mathrm{Zr}\left(\mathrm{OC}_{2} \mathrm{H}_{5}\right)\right)_{2}\left(\mathrm{BOC}_{2} \mathrm{H}_{5}\right)\right\}\right]\left[\mathrm{HB}\left(\mathrm{C}_{6} \mathrm{~F}_{5}\right)_{3}\right]$, 5, showing $30 \%$ probability thermal ellipsoids.

on the boron atom. The $\mathrm{Zr}-\mathrm{B}$ distances and the hydrogen bridge $\mathrm{Zr}-\mathrm{H}_{\mathrm{b}}$ bond distances of compounds $\mathbf{1}$ and $\mathbf{3}$ are in the range

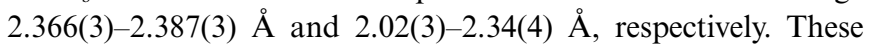
distances are consistent with those generally observed for the tridentate bonding mode, namely, the $\mathrm{Zr}-\mathrm{B}$ distances in the range of 2.276(11)-2.403(29) $\AA$ and the $\mathrm{Zr}-\mathrm{H}_{\mathrm{b}}$ bond distances in the range of 2.04(5)-2.36(7) $\AA . .^{14,19}$
Table 2 Crystal data and structure refinement for $\left[\left(\mu_{3}-\mathrm{O}\right)\left(\mu_{2}-\right.\right.$ $\left.\left.\mathrm{OC}_{2} \mathrm{H}_{5}\right)_{3}\left\{\left(\mathrm{Cp}^{*} \mathrm{Zr}\left(\mathrm{OC}_{2} \mathrm{H}_{5}\right)\right)_{2}\left(\mathrm{BCH}_{3}\right)\right\}\right]\left[\mathrm{HB}\left(\mathrm{C}_{6} \mathrm{~F}_{5}\right)_{3}\right], \quad 4$, and $\left[\left(\mu_{3}-\mathrm{O}\right)\left(\mu_{2}-\right.\right.$ $\left.\left.\mathrm{OC}_{2} \mathrm{H}_{5}\right)_{3}\left\{\left(\mathrm{Cp}^{*} \mathrm{Zr}\left(\mathrm{OC}_{2} \mathrm{H}_{5}\right)\right)_{2}\left(\mathrm{BOC}_{2} \mathrm{H}_{5}\right)\right\}\right]\left[\mathrm{HB}\left(\mathrm{C}_{6} \mathrm{~F}_{5}\right)_{3}\right], \mathbf{5}$

\begin{tabular}{lll}
\hline Empirical formula & $\mathrm{C}_{49} \mathrm{H}_{59} \mathrm{~B}_{2} \mathrm{~F}_{15} \mathrm{O}_{6} \mathrm{Zr}_{2}$ & $\mathrm{C}_{50} \mathrm{H}_{60} \mathrm{~B}_{2} \mathrm{~F}_{15} \mathrm{O}_{7} \mathrm{Zr}_{2}$ \\
$M$ & 1233.02 & 1262.04 \\
$T / \mathrm{K}$ & $150(2)$ & $295(2)$ \\
Crystal system & Monoclinic & Orthorhombic \\
Space group & $P 2(1) / c$ & $P 2(1) 2(1) 2(1)$ \\
$a / \AA$ & $10.5767(5)$ & $14.6566(5)$ \\
$b / \AA$ & $16.4862(8)$ & $18.0175(6)$ \\
$c / \AA$ & $32.1655(17)$ & $20.3699(7)$ \\
$\beta /{ }^{\circ}$ & $93.389(1)$ & \\
$V / \AA^{3}$ & $5598.9(5)$ & $5379.2(3)$ \\
$Z$ & 4 & 4 \\
$\rho_{\text {calcd }} / \mathrm{g}$ cm & \\
Crystal size/mm & 1.463 & 1.558 \\
Radiation $(\lambda / \AA)$ & $0.50 \times 0.32 \times 0.20$ & $0.36 \times 0.30 \times 0.25$ \\
$\theta$ limits/ & $\mathrm{Mo}-\mathrm{K} \alpha(0.71073)$ & $\mathrm{Mo}-\mathrm{K} \alpha(0.71073)$ \\
Index ranges & $1.27-27.50$ & $1.51-27.49$ \\
& $-13 \leq h \leq 12$ & $-18 \leq h \leq 19$ \\
& $-21 \leq k \leq 17$ & $-23 \leq k \leq 23$ \\
Reflns collected & $-41 \leq l \leq 41$ & $-26 \leq l \leq 26$ \\
Unique reflns & 49575 & 54149 \\
$F(000)$ & 12748 & 12348 \\
Completeness to $\theta(\%)$ & 2504 & 2564 \\
$\mu /$ mm ${ }^{-1}$ & 99.2 & 100.0 \\
Max., min. transm. & 0.466 & 0.488 \\
Data/restraints/params & $0.9126,0.8005$ & $0.8877,0.8438$ \\
$R_{1}{ }^{a}[I>2.0 \sigma(I)]$ & $12748 / 4 / 689$ & $12348 / 2 / 704$ \\
$w R_{2}{ }^{b}$ (all data $)$ & 0.0695 & 0.0412 \\
$R_{\text {int }}$ & 0.2137 & 0.0899 \\
GOF on $F^{2}$ & 0.0591 & 0.0591 \\
& 1.089 & 1.029 \\
${ }^{a} R_{1}=\sum\left\|F_{\mathrm{o}}\right\|-\left|F_{\mathrm{c}}\left\|/ \sum\right\| F_{\mathrm{o}}\right|{ }^{b} w R_{2}=\left\{\sum w\left(F_{\mathrm{o}}{ }^{2}-F_{\mathrm{c}}{ }^{2}\right)^{2} / \sum w\left(F_{\mathrm{o}}{ }^{2}\right)^{2}\right\}^{1 / 2}$. \\
\hline
\end{tabular}


Table 3 Selected bond lengths $(\AA)$ and angles $\left(^{\circ}\right)$ for $\mathrm{Cp} * \mathrm{Zr}\left(\mathrm{BH}_{3} \mathrm{CH}_{3}\right)_{3}$, 1, $\mathrm{Cp}^{*} \mathrm{Zr}\left(\mathrm{BH}_{3} \mathrm{Ph}\right)_{3}, \mathbf{2}$, and $\mathrm{Cp} * \mathrm{Zr}\left(\mathrm{BH}_{4}\right)_{3}, 3$

\begin{tabular}{|c|c|c|c|}
\hline & 1 & 2 & 3 \\
\hline \multirow[t]{3}{*}{$\mathrm{Zr}-\mathrm{B}$} & $2.367(3)$ & $2.375(3)$ & $2.366(3)$ \\
\hline & $2.374(3)$ & $2.389(3)$ & $2.369(4)$ \\
\hline & $2.387(3)$ & $2.413(4)$ & $2.378(4)$ \\
\hline \multirow[t]{9}{*}{$\mathrm{Zr}-\mathrm{H}_{\mathrm{b}}$} & $2.02(4)$ & $2.04(3)$ & $2.02(3)$ \\
\hline & $2.03(5)$ & $2.04(3)$ & $2.03(3)$ \\
\hline & $2.04(4)$ & $2.05(3)$ & $2.08(3)$ \\
\hline & $2.06(4)$ & $2.14(3)$ & $2.09(4)$ \\
\hline & $2.10(4)$ & $2.15(3)$ & $2.11(4)$ \\
\hline & $2.18(4)$ & $2.22(3)$ & $2.13(3)$ \\
\hline & $2.29(4)$ & $2.26(3)$ & $2.29(4)$ \\
\hline & $2.31(4)$ & $2.30(3)$ & $2.33(3)$ \\
\hline & $2.33(3)$ & & $2.34(4)$ \\
\hline $\mathrm{Zr} \cdots \mathrm{H}$ & & 2.475 & \\
\hline \multirow{9}{*}{ B- $\mathrm{H}_{\mathrm{b}}$} & $1.06(4)$ & $1.08(3)$ & $1.02(3)$ \\
\hline & $1.09(3)$ & $1.09(3)$ & $1.02(4)$ \\
\hline & $1.14(4)$ & $1.09(3)$ & $1.05(4)$ \\
\hline & $1.14(4)$ & $1.09(3)$ & $1.07(4)$ \\
\hline & $1.17(4)$ & $1.12(3)$ & $1.08(4)$ \\
\hline & $1.17(4)$ & $1.14(3)$ & $1.11(4)$ \\
\hline & $1.21(4)$ & $1.15(3)$ & $1.12(4)$ \\
\hline & $1.22(4)$ & $1.18(2)$ & $1.16(3)$ \\
\hline & $1.29(3)$ & $1.22(3)$ & $1.20(4)$ \\
\hline \multirow[t]{3}{*}{$\mathrm{B}-\mathrm{H}_{\mathrm{t}}$} & & & $1.06(4)$ \\
\hline & & & $1.09(4)$ \\
\hline & & & $1.11(4)$ \\
\hline \multirow{3}{*}{$\mathrm{Zr}-\mathrm{B}-\mathrm{R}_{\mathrm{t}}{ }^{a}$} & $168.2(2)$ & $163.4(2)$ & $168(2)$ \\
\hline & $172.3(2)$ & $171.8(2)$ & $170(2)$ \\
\hline & $174.2(3)$ & $174.9(2)$ & $171(2)$ \\
\hline
\end{tabular}

The $\mathrm{Zr}-\mathrm{B}$ distances in 2 are 2.375(3), 2.389(3), and 2.413(4) $\AA$. The two short $\mathrm{Zr}-\mathrm{B}$ distances and their corresponding $\mathrm{Zr}-\mathrm{H}_{\mathrm{b}}$ distances are consistent with the tridentate bonding mode. The $\mathrm{Zr}$-B distance of 2.413(4) $\AA$ is longer than expected for a bond distance characteristic of the tridentate mode. The corresponding $\mathrm{Zr}-\mathrm{H}$ distance of $2.475 \AA$ is significantly longer than the sum of the covalent radii of $\mathrm{Zr}$ and $\mathrm{H}$ atoms (1.91 $\AA$ ) and generally observed $\mathrm{Zr}-\mathrm{H}_{\mathrm{b}}$ distances. However, it is shorter than a sum of the covalent radius of $\operatorname{Zr}(1.50 \AA)^{20}$ and the van der Waals radius of $\mathrm{H}(1.20 \AA) .{ }^{21} \mathrm{An}$ additional piece of judgment in favor of the tridentate bonding mode is the linearity of the $\mathrm{Zr}-\mathrm{B}-\mathrm{C}$ angles. The corresponding $\mathrm{Zr}-\mathrm{B}-\mathrm{C}$ angle is $163.4(2)^{\circ}$, which is $5^{\circ}$ smaller than the smallest of $\mathrm{Zr}-\mathrm{B}-\mathrm{C}\left(\mathrm{H}_{\mathrm{t}}\right)$ angles in $\mathbf{1}$ and $\mathbf{3}$. Thus, the longest $\mathrm{Zr}-\mathrm{H}$ distance of $2.475 \AA$ would suggest an agostic interaction between $\mathrm{Zr}$ and $\mathrm{H}$, and the coordination between the $\mathrm{Zr}$ and this phenyltrihydroborate ligand could be described as an intermediate between the bidentate and tridentate modes. This deviation from the tridentate bonding mode can be accounted for by steric reasons. It is worth noting that the average $\mathrm{B}-\mathrm{H}_{\mathrm{b}}$ and $\mathrm{B}-$ $\mathrm{H}_{\mathrm{t}}$ distances in $\mathbf{3}$ are about the same (1.09 $\AA$ ). This is in contrast with an observation that for most tetrahydroborate compounds the $\mathrm{B}-\mathrm{H}_{\mathrm{b}}$ distances are slightly longer than the $\mathrm{B}-\mathrm{H}_{\mathrm{t}}$ distances. ${ }^{1,22}$

Compounds 4 and 5 are ionic, with cation charges being balanced by that of the $\left[\mathrm{HB}\left(\mathrm{C}_{6} \mathrm{~F}_{5}\right)_{3}\right]^{-}$anion. The molecular structures of these cations are similar. A $\mu_{3}$-oxygen bridges two zirconiums and a boron atom, and these three atoms are further connected through three $\mu_{2}$-bridging ethoxy groups. Overall, there are three four-membered metallacycles within the structure of each cation. The bond angles in each of the four-membered rings in both cations are also comparable. Except for those of $\mathrm{Zr} 1-\mathrm{O} 4-\mathrm{B} 1$

Table 4 Selected bond lengths $(\AA)$ and angles $\left(^{\circ}\right)$ for $\left[\left(\mu_{3}-\mathrm{O}\right)\left(\mu_{2}-\mathrm{OC}_{2} \mathrm{H}_{5}\right)_{3}\left\{\left(\mathrm{Cp}^{*} \mathrm{Zr}\left(\mathrm{OC}_{2} \mathrm{H}_{5}\right)\right)_{2}\left(\mathrm{BCH}_{3}\right)\right\}\right]\left[\mathrm{HB}\left(\mathrm{C}_{6} \mathrm{~F}_{5}\right)_{3}\right], \quad 4, \quad$ and $\left[\left(\mu_{3}-\mathrm{O}\right)\left(\mu_{2}-\right.\right.$ $\left.\left.\mathrm{OC}_{2} \mathrm{H}_{5}\right)_{3}\left\{\left(\mathrm{Cp} * \mathrm{Zr}\left(\mathrm{OC}_{2} \mathrm{H}_{5}\right)\right)_{2}\left(\mathrm{BOC}_{2} \mathrm{H}_{5}\right)\right\}\right]\left[\mathrm{HB}\left(\mathrm{C}_{6} \mathrm{~F}_{5}\right)_{3}\right], 5$

\begin{tabular}{|c|c|c|c|c|c|}
\hline & 4 & 5 & & 4 & 5 \\
\hline $\mathrm{Zr}(1)-\mathrm{O}(1)$ & $2.147(3)$ & $2.120(2)$ & $\mathrm{O}(3)-\mathrm{C}(3)$ & $1.428(7)$ & $1.407(5)$ \\
\hline $\mathrm{Zr}(1)-\mathrm{O}(2)$ & $2.177(3)$ & $2.149(2)$ & $\mathrm{O}(4)-\mathrm{C}(5)$ & $1.433(7)$ & $1.433(4)$ \\
\hline $\mathrm{Zr}(1)-\mathrm{O}(4)$ & $2.178(4)$ & $2.194(2)$ & $\mathrm{O}(6)-\mathrm{C}(9)$ & $1.419(8)$ & $1.417(4)$ \\
\hline $\mathrm{Zr}(2)-\mathrm{O}(1)$ & $2.121(3)$ & $2.156(2)$ & $\mathrm{O}(7)-\mathrm{C}(11)$ & & $1.431(4)$ \\
\hline $\mathrm{Zr}(2)-\mathrm{O}(2)$ & $2.144(3)$ & $2.161(2)$ & $\mathrm{O}(1)-\mathrm{B}(1)$ & $1.460(7)$ & $1.454(4)$ \\
\hline $\mathrm{Zr}(2)-\mathrm{O}(5)$ & $2.174(4)$ & $2.200(2)$ & $\mathrm{O}(4)-\mathrm{B}(1)$ & $1.532(8)$ & $1.521(4)$ \\
\hline $\mathrm{O}(2)-\mathrm{C}(1)$ & $1.474(7)$ & $1.449(4)$ & $\mathrm{B}(1)-\mathrm{C}(11)$ & $1.578(9)$ & \\
\hline $\mathrm{O}(3)-\mathrm{Zr}(1)-\mathrm{O}(2)$ & $90.82(15)$ & $91.40(10)$ & $\mathrm{C}(3)-\mathrm{O}(3)-\mathrm{Zr}(1)$ & $170.5(4)$ & $169.3(3)$ \\
\hline $\mathrm{O}(3)-\mathrm{Zr}(1)-\mathrm{O}(4)$ & $90.78(16)$ & $89.10(10)$ & $\mathrm{C}(5)-\mathrm{O}(4)-\mathrm{Zr}(1)$ & $138.9(4)$ & $132.5(2)$ \\
\hline $\mathrm{O}(1)-\mathrm{Zr}(1)-\mathrm{O}(2)$ & $70.91(13)$ & $71.16(8)$ & $\mathrm{C}(7)-\mathrm{O}(5)-\mathrm{Zr}(2)$ & $136.9(4)$ & $136.9(2)$ \\
\hline $\mathrm{O}(1)-\mathrm{Zr}(1)-\mathrm{O}(4)$ & $63.35(13)$ & $63.38(8)$ & $\mathrm{C}(9)-\mathrm{O}(6)-\mathrm{Zr}(2)$ & $175.1(6)$ & $164.1(3)$ \\
\hline $\mathrm{O}(6)-\mathrm{Zr}(2)-\mathrm{O}(5)$ & $89.00(19)$ & $93.06(10)$ & $\mathrm{O}(5)-\mathrm{B}(1)-\mathrm{O}(4)$ & $110.3(5)$ & $112.5(3)$ \\
\hline $\mathrm{B}(1)-\mathrm{O}(1)-\mathrm{Zr}(1)$ & $100.8(3)$ & $100.14(18)$ & $\mathrm{O}(1)-\mathrm{B}(1)-\mathrm{C}(11)$ & $120.2(6)$ & \\
\hline $\mathrm{B}(1)-\mathrm{O}(1)-\mathrm{Zr}(2)$ & 101.4(3) & $100.5(2)$ & $\mathrm{O}(5)-\mathrm{B}(1)-\mathrm{C}(11)$ & $113.4(5)$ & \\
\hline $\mathrm{B}(1)-\mathrm{O}(4)-\operatorname{Zr}(1)$ & $97.1(3)$ & $94.82(17)$ & $\mathrm{O}(4)-\mathrm{B}(1)-\mathrm{C}(11)$ & $114.2(5)$ & \\
\hline $\mathrm{B}(1)-\mathrm{O}(5)-\mathrm{Zr}(2)$ & $97.1(3)$ & $96.76(18)$ & $\mathrm{B}(1)-\mathrm{O}(7)-\mathrm{C}(11)$ & & $117.3(3)$ \\
\hline $\mathrm{Zr}(2)-\mathrm{O}(1)-\mathrm{Zr}(1)$ & $104.18(15)$ & 103.62(9) & $\mathrm{O}(7)-\mathrm{B}(1)-\mathrm{O}(1)$ & & $120.7(3)$ \\
\hline $\mathrm{C}(1)-\mathrm{O}(2)-\mathrm{Zr}(1)$ & $126.7(3)$ & $119.0(2)$ & $\mathrm{O}(7)-\mathrm{B}(1)-\mathrm{O}(5)$ & & $108.8(3)$ \\
\hline $\mathrm{C}(1)-\mathrm{O}(2)-\mathrm{Zr}(2)$ & $117.4(3)$ & $126.7(2)$ & $\mathrm{O}(7)-\mathrm{B}(1)-\mathrm{O}(4)$ & & $114.7(3)$ \\
\hline
\end{tabular}


(97.1(3) in 4, 94.82(17) in 5), O4-B1-O1 (98.8(4) in 4, 99.3(3) in 5), and O1-B1-O5 (98.0(4) in 4, 99.8(3) in 5), the difference for each pair of angles is less than $1^{\circ}$. Each zirconium atom in $\mathbf{4}$ and $\mathbf{5}$ is further coordinated to a $\mathrm{Cp}^{*}$ ring and a terminal ethoxy group. Thus, the coordination of each zirconium can be described best as a distorted square pyramid with a $\mathrm{Cp}^{*}$ ring occupying the apical position and four oxygens occupying four distorted basal sites. The boron atom is tetra-coordinated, in addition to three oxygens it is either bonded to a methyl group in $\mathbf{4}$ or an additional ethoxy group in $\mathbf{5}$.

The terminal $\mathrm{Zr}-\mathrm{O}$ bond distances are about $1.908 \AA$ in both compounds. This distance falls in the range 1.89-1.94 $\AA$ observed previously for the terminal $\mathrm{Zr}-\mathrm{O}$ distances in zirconium alkoxides. ${ }^{23,24}$ The corresponding $\mathrm{Zr}-\mathrm{O}-\mathrm{C}$ angles of 170.5(4), 175.1(6) ${ }^{\circ}$ in 4 and 169.3(3), 164.1(3) ${ }^{\circ}$ in $\mathbf{5}$ are consistent with a strong $\mathrm{O} \rightarrow \mathrm{Zr} \pi$-donation ${ }^{17}$ or an increased ionic character of the $\mathrm{Zr}-\mathrm{O}$ bond. ${ }^{20,25}$ The bridging $\mathrm{Zr}-\mathrm{O}$ bond distances vary in both cations. However, they increase in the order $\mathrm{Zr}-\mathrm{O} 1<\mathrm{Zr}$ $\mathrm{O} 2<\mathrm{Zr}-\mathrm{O} 4, \mathrm{Zr}-\mathrm{O} 5$, and are longer than those of the terminal $\mathrm{Zr}-\mathrm{O}$ bonds. These bridging $\mathrm{Zr}-\mathrm{O}$ bond distances fall in the range 2.121(3)-2.178(4) $\AA$ in 4 and 2.120(2)-2.200(2) $\AA$ in 5. They are comparable with the bridging $\mathrm{Zr}-\mathrm{O}$ distances in other zirconium alkoxides and zirconium oxides (2.098(8)-2.2215(2) $\AA$ ).${ }^{17,24,26}$ The bonding environments of $\mathrm{O} 4$ and $\mathrm{O} 5$ in $\mathbf{4}$ and $\mathrm{O} 5$ in $\mathbf{5}$ are nearly planar. The sums of angles around these oxygens are 357.5, 356.6, and $356.4^{\circ}$, respectively. Other bridging oxygens are nonplanar, with the sums of the angles around $\mathrm{O} 1$ and $\mathrm{O} 2$ being 306.38 and $346.54^{\circ}$ in $\mathbf{4}$, and 304.26 and $348.17^{\circ}$ in $\mathbf{5}$.

\section{Conclusions}

Novel $\mu_{3}$-oxo compounds, 4 and 5, were isolated from the reactions of half-sandwich zirconocene hydroborate compounds with $\mathrm{B}\left(\mathrm{C}_{6} \mathrm{~F}_{5}\right)_{3}$. Although $\mathrm{C}-\mathrm{O}$ bond cleavage mediated by Group 4 metal complexes is not uncommon, it is the structure of these compounds possessing three four-membered metallacycles that is unique. It is possible that these $\mu_{3}$-oxo compounds form as a result of the sequential cleavage of $\mathrm{Zr}-\mathrm{H}-\mathrm{B}$ bonds and $\mathrm{C}-\mathrm{O}$ bonds of ether, and the formation of $\mathrm{B}-\mathrm{O}$ bonds, albeit at this point it could not be corroborated by observation of the corresponding intermediates.

\section{Experimental section}

All manipulations were carried out on a standard high vacuum line or in a drybox under an atmosphere of nitrogen. Diethyl ether and hexane were dried over $\mathrm{Na}$ /benzophenone and were freshly distilled prior to use. $\mathrm{Cp}^{*} \mathrm{ZrCl}_{3}, \mathrm{LiBH}_{4}$, and $\mathrm{B}\left(\mathrm{C}_{6} \mathrm{~F}_{5}\right)_{3}$ were purchased from Strem Chemicals and used as received. $\mathrm{LiBH}_{3} \mathrm{CH}_{3},{ }^{16} \mathrm{LiBH}_{3} \mathrm{Ph},{ }^{16}$ and $\mathrm{Cp} * \mathrm{Zr}\left(\mathrm{BH}_{4}\right)_{3}{ }^{15}$ were prepared according to literature methods. Elemental analyses were obtained on a Hitachi $270-30$ spectrometer. Proton spectra $(\delta($ TMS $)=$ $0.00 \mathrm{ppm}$ ) were recorded either on a Bruker Avance DPX300 spectrometer operating at $300.132 \mathrm{MHz}$ or Bruker Avance II spectrometer operating at $400.130 \mathrm{MHz} .{ }^{11} \mathrm{~B}$ spectra (externally referenced to $\left.\mathrm{BF}_{3} \cdot \mathrm{OEt}_{2}(\delta=0.00 \mathrm{ppm})\right)$ were recorded on a Bruker Avance DPX300 spectrometer operating at 96.294 MHz. Infrared spectra were recorded on a Jasco FT/IR-460 Plus spectrometer with $2 \mathrm{~cm}^{-1}$ resolution.

\section{X-Ray crystal structure determination}

Suitable single crystals were mounted and sealed inside glass fibers under nitrogen. Crystallographic data collections were carried out on a Nonius KappaCCD diffractometer with graphite monochromated Mo-K $\alpha$ radiation $(\lambda=0.71073 \AA$ ) at $150(2) \mathrm{K}$ and $295(2)$ $\mathrm{K}$. Cell parameters were retrieved and refined using DENZO$\mathrm{SMN}^{27}$ software on all reflections. Data reduction was performed with the DENZO-SMN ${ }^{27}$ software. An empirical absorption was based on the symmetry-equivalent reflections and was applied to the data using the $\mathrm{SORTAV}^{28}$ program. Structure analysis was made using the SHELXTL program on a personal computer. The structure was solved using the SHELXS- $97^{29}$ program and refined using the SHELXL-97 ${ }^{30}$ program by full-matrix least-squares on $F^{2}$ values. All non-hydrogen atoms were refined anisotropically. Hydrogen atoms attached to the borons were found from the difference Fourier map and refined isotropically. Hydrogen atoms attached to the carbons were fixed at calculated positions and refined using a riding mode. Detailed crystal data are listed in Tables 1 and 2 .

\section{Preparation of $\mathrm{Cp} * \mathrm{Zr}\left(\mathrm{BH}_{3} \mathrm{CH}_{3}\right)_{3} 1$}

In the drybox $\mathrm{Cp}^{*} \mathrm{ZrCl}_{3}(333.0 \mathrm{mg}, 1.0 \mathrm{mmol})$ and $\mathrm{LiBH}_{3} \mathrm{CH}_{3}$ $(111.0 \mathrm{mg}, 3.1 \mathrm{mmol})$ were placed into a flask. The flask was evacuated, and $20 \mathrm{~mL}$ of diethyl ether was condensed into it at $-78{ }^{\circ} \mathrm{C}$. The system was warmed to room temperature and stirred overnight. The $\mathrm{LiCl}$ thus formed was separated from the solution by filtration. A white solid was obtained after removal of the solvent from the filtrate. Colorless crystals of $\mathbf{1}$ $(240.0 \mathrm{mg}, 77 \%$ yield) were obtained after crystallization from $\mathrm{Et}_{2} \mathrm{O}$ at $-35^{\circ} \mathrm{C}$. IR(KBr, cm $\left.{ }^{-1}\right): 2980 \mathrm{~m}, 2939$ s, $2904 \mathrm{~m}, 2854 \mathrm{w}$, 2831w, 2238vw, 2169vw, 2065br, s, 1652vw, 1632vw, 1487w, 1461w, $1430 \mathrm{~m}, 1376 \mathrm{w}, 1308 \mathrm{~s}, 1227 \mathrm{vs}, 1104 \mathrm{w}, 1073 \mathrm{w}, 1020 \mathrm{w}, 962 \mathrm{w}, 805 \mathrm{vw}$, $679 \mathrm{vw}$ and $667 \mathrm{vw} .{ }^{11} \mathrm{~B}$ NMR (diethyl ether, $\delta$ ): $-5.60 \mathrm{ppm}\left(\mathrm{q}, J_{\mathrm{B}-\mathrm{H}}\right.$ 69). ${ }^{11} \mathrm{~B}$ NMR $\left(\mathrm{C}_{6} \mathrm{D}_{6}, \delta\right):-5.50 \mathrm{ppm}\left(\mathrm{q}, J_{\mathrm{B}-\mathrm{H}} 69\right) .{ }^{1} \mathrm{H} \mathrm{NMR}\left(\mathrm{C}_{6} \mathrm{D}_{6}\right.$, $\delta): 1.84\left(15 \mathrm{H}, \mathrm{s}, \mathrm{Cp}^{*}\right), 1.37\left(9 \mathrm{H}\right.$, br q, $\left.\mathrm{BH}_{3}\right)$ and $0.49 \mathrm{ppm}(9 \mathrm{H}$, br q, $J_{\mathrm{H}-\mathrm{H}} 4.2, \mathrm{CH}_{3}$,). Anal. Found: C, 49.81; H, 10.63. Calc. for $\mathrm{C}_{13} \mathrm{H}_{33} \mathrm{~B}_{3} \mathrm{Zr}$ : C, 49.88; H, 10.63\%.

\section{Preparation of of $\mathrm{Cp} * \mathrm{Zr}\left(\mathrm{BH}_{3} \mathrm{Ph}\right)_{3} 2$}

A $50 \mathrm{~mL}$ flask was charged with $332.8 \mathrm{mg}(1.0 \mathrm{mmol})$ of $\mathrm{Cp} * \mathrm{ZrCl}_{3}$ and $294.0 \mathrm{mg}(3.0 \mathrm{mmol})$ of $\mathrm{LiBH}_{3} \mathrm{Ph}$. The flask was evacuated, and about $15 \mathrm{~mL}$ of $\mathrm{Et}_{2} \mathrm{O}$ was condensed into it at $-78^{\circ} \mathrm{C}$. The system was warmed to room temperature and stirred for $12 \mathrm{~h}$. The $\mathrm{LiCl}$ was removed by filtration followed by solvent removal under vacuum. The white solid left in the flask was dissolved in $\mathrm{Et}_{2} \mathrm{O}$ and kept at $-35^{\circ} \mathrm{C}$ for crystallization furnishing $\mathbf{2}$ as colorless crystals (290 mg, 58\% yield). IR( $\left.\mathrm{KBr}, \mathrm{cm}^{-1}\right): 3067 \mathrm{vw}, 3056 \mathrm{vw}, 3010 \mathrm{vw}$, $2977 \mathrm{vw}, 2962 \mathrm{vw}, 2916 \mathrm{vw}, 2860 \mathrm{vw}, 2215 \mathrm{br}$, vw, 2076br, m, 1944vw, $1490 \mathrm{vw}, 1483 \mathrm{vw}, 1432 \mathrm{w}, 1426 \mathrm{vw}, 1382 \mathrm{w}, 1364 \mathrm{vw}, 1341 \mathrm{w}, 1283 \mathrm{~s}$, $1265 \mathrm{vs}, 1160 \mathrm{~m}, 1151 \mathrm{~m}, 1125 \mathrm{~s}, 1088 \mathrm{w}, 1054 \mathrm{w}, 1028 \mathrm{~m}, 1000 \mathrm{w}$, 983vw, 908vw, 804w, 793w, 739s, 733s, 698s, 670vw, 663vw, 574w and 471vw. ${ }^{11} \mathrm{~B}$ NMR $\left(\mathrm{C}_{6} \mathrm{D}_{6}, \delta\right):-4.32 \mathrm{ppm}$ (br). ${ }^{1} \mathrm{H}$ NMR $\left(\mathrm{C}_{6} \mathrm{D}_{6}, \delta\right): 7.56-7.09(15 \mathrm{H}, \mathrm{m}, \mathrm{Ph}), 2.28 \mathrm{ppm}\left(9 \mathrm{H}\right.$, br q, $\left.\mathrm{BH}_{3}\right)$ and $1.84\left(15 \mathrm{H}, \mathrm{s}, \mathrm{Cp}^{*}\right)$. Anal. Found: C, 66.82; H, 7.83. Calc. for $\mathrm{C}_{28} \mathrm{H}_{39} \mathrm{~B}_{3} \mathrm{Zr}: \mathrm{C}, 67.36$; H, 7.87\%. 


\section{Preparation of $\left[\left(\mu_{3}-\mathrm{O}\right)\left(\mu_{2}-\mathrm{OC}_{2} \mathrm{H}_{5}\right)_{3}\{(\mathrm{Cp} * \mathrm{Zr}-\right.$ $\left.\left.\left.\left(\mathrm{OC}_{2} \mathrm{H}_{5}\right)\right)_{2}\left(\mathrm{BCH}_{3}\right)\right\}\right]\left[\mathrm{HB}\left(\mathrm{C}_{6} \mathrm{~F}_{5}\right)_{3}\right] 4$}

In the drybox $156.0 \mathrm{mg}(0.5 \mathrm{mmol})$ of $\mathrm{Cp}^{*} \mathrm{Zr}\left(\mathrm{BH}_{3} \mathrm{CH}_{3}\right)_{3}$ and $256.0 \mathrm{mg}(0.5 \mathrm{mmol})$ of $\mathrm{B}\left(\mathrm{C}_{6} \mathrm{~F}_{5}\right)_{3}$ were placed into a $50 \mathrm{~mL}$ flask. The flask was degassed, and about $10 \mathrm{~mL}$ of diethyl ether was transferred into it at $-78{ }^{\circ} \mathrm{C}$. The system was warmed to room temperature and stirred overnight. After reducing the volume of the clear solution to about $3 \mathrm{~mL}$, it was transferred into a tube and layered with hexane for crystallization. The title compound was obtained as colorless crystals (140.0 mg, 45\% yield). IR(KBr, cm $\left.{ }^{-1}\right): 2980 \mathrm{w}, 2927 \mathrm{w}, 2870 \mathrm{vw}, 2403 \mathrm{vw}, 1636 \mathrm{w}$, $1506 \mathrm{~m}, 1465 \mathrm{vs}, 1380 \mathrm{w}, 1319 \mathrm{vw}, 1273 \mathrm{~m}, 1250 \mathrm{vw}, 1119 \mathrm{~m}, 1069 \mathrm{~m}$, $1036 \mathrm{w}, 970 \mathrm{~s}, 931 \mathrm{w}, 878 \mathrm{vw}, 805 \mathrm{vw}, 764 \mathrm{vw}, 710 \mathrm{vw}, 667 \mathrm{vw}, 656 \mathrm{vw}$, 599vw, 583vw, 564vw, 549vw and 461vw. ${ }^{11} \mathrm{~B}$ NMR (diethyl ether, $\delta$ ): 30.64 (s) and $-25.85 \mathrm{ppm}\left(\mathrm{d}, J_{\mathrm{B}-\mathrm{H}} 93\right) .{ }^{11} \mathrm{~B}$ NMR $\left(\mathrm{d}_{8}-\mathrm{THF}, \delta\right)$ : 30.46 (s) and -26.09 ppm (d, $\left.J_{\mathrm{B}-\mathrm{H}} 93\right)$. Anal. Found: C, 47.32; $\mathrm{H}$, 4.60. Calc. for $\mathrm{C}_{49} \mathrm{H}_{59} \mathrm{~B}_{2} \mathrm{~F}_{15} \mathrm{O}_{6} \mathrm{Zr}_{2}$ : C, 47.73; H, 4.82\%.

\section{Preparation of $\left[\left(\mu_{3}-\mathrm{O}\right)\left(\mu_{2}-\mathrm{OC}_{2} \mathrm{H}_{5}\right)_{3}\left\{\left(\mathrm{Cp}^{*} \mathrm{Zr}\right.\right.\right.$ - $\left.\left.\left.\left(\mathrm{OC}_{2} \mathrm{H}_{5}\right)\right)_{2}\left(\mathrm{BOC}_{2} \mathrm{H}_{5}\right)\right\}\right]\left[\mathrm{HB}\left(\mathrm{C}_{6} \mathrm{~F}_{5}\right)_{3}\right] 5$}

In the drybox $135.0 \mathrm{mg}(0.5 \mathrm{mmol})$ of $\mathrm{Cp} * \mathrm{Zr}\left(\mathrm{BH}_{4}\right)_{3}$ and $256.0 \mathrm{mg}$ $(0.5 \mathrm{mmol})$ of $\mathrm{B}\left(\mathrm{C}_{6} \mathrm{~F}_{5}\right)_{3}$ were placed into a $50 \mathrm{~mL}$ flask. The flask was degassed, and about $10 \mathrm{~mL}$ of diethyl ether was transferred into it at $-78^{\circ} \mathrm{C}$. The system was warmed to room temperature and stirred overnight. After reducing the volume of the clear solution to about $3 \mathrm{~mL}$, it was transferred into a tube and layered with hexane for crystallization. The title compound was obtained as colorless crystals $\left(190.0 \mathrm{mg}, 60 \%\right.$ yield). $\mathrm{IR}\left(\mathrm{KBr}, \mathrm{cm}^{-1}\right): 2985 \mathrm{w}$, 2923w, 2879vw, 2404vw, 1648m, 1602vw, 1520m, 1508m, 1466vs, $1381 \mathrm{~m}, 1349 \mathrm{vw}, 1322 \mathrm{vw}, 1274 \mathrm{w}, 1197 \mathrm{w}, 1160 \mathrm{vw}, 1106 \mathrm{~m}, 1078 \mathrm{~m}$, $1025 \mathrm{w}, 972 \mathrm{~s}, 879 \mathrm{vw}, 834 \mathrm{vw}, 787 \mathrm{w}, 762 \mathrm{w}, 743 \mathrm{vw}, 727 \mathrm{vw}, 688 \mathrm{w}$, 674w, 663w, 622vw, 600vw, 567vw, 554vw and 471vw. ${ }^{11} \mathrm{~B}$ NMR (diethyl ether, $\delta$ ): 17.62 (s) and $-25.87 \mathrm{ppm}\left(\mathrm{d}, J_{\mathrm{B}-\mathrm{H}} 93\right) .{ }^{11} \mathrm{~B}$ NMR $\left(\mathrm{d}_{8}\right.$-toluene, $\delta$ ): $17.63(\mathrm{~s})$ and $-25.92 \mathrm{ppm}\left(\mathrm{d}, J_{\mathrm{B}-\mathrm{H}} 94\right) .{ }^{1} \mathrm{H}$ NMR $\left(\mathrm{d}_{8}\right.$-toluene, $\left.\delta\right): 3.19\left(\mathrm{q}, J_{\mathrm{H}-\mathrm{H}} 7.0, \mathrm{CH}_{2}\right), 1.81\left(\mathrm{~s}, \mathrm{Cp}^{*}\right)$ and 0.98 $\left(\mathrm{t}, J_{\mathrm{H}-\mathrm{H}} 7.0, \mathrm{CH}_{3}\right) \cdot{ }^{13} \mathrm{C}$ NMR $\left(\mathrm{d}_{8}\right.$-toluene, $\left.\delta\right): 122.0\left(\mathrm{CCH}_{3}\right), 65.55$ $\left(\mathrm{CH}_{2}\right), 14.61\left(\mathrm{CH}_{3}\right)$ and $10.69 \mathrm{ppm}\left(\mathrm{CCH}_{3}\right)$. Anal. Found: $\mathrm{C}, 47.09$; $\mathrm{H}$, 4.75. Calc. for $\mathrm{C}_{50} \mathrm{H}_{61} \mathrm{~B}_{2} \mathrm{~F}_{15} \mathrm{O}_{7} \mathrm{Zr}_{2}$ : C, 47.55; H, 4.87\%.

\section{Acknowledgements}

This work was supported by the National Science Council of the ROC through Grant NSC 95-2113-M-259-011.

\section{References}

1 T. J. Marks and J. R. Kolb, Chem. Rev., 1977, 77, 163.

2 F. Volatron, M. Duran, A. Lledos and Y. Jean, Inorg. Chem., 1993, 32, 951.

3 B. Tamami and N. I. Goudarzian, J. Chem. Soc., Chem. Commun., 1994, 1079.

4 B. D. James, R. K. Nanda and M. G. H. Wallbridge, Inorg. Chem., 1967, 6, 1979; M. D. Fryzuk, S. J. Rettig, A. Westerhaus and H. D.
Williams, Inorg. Chem., 1985, 24, 4316; J. E. Gozum, S. R. Wilson and G. S. Girolami, J. Am. Chem. Soc., 1992, 114, 9483; J. E. Gozum and G. S. Girolami, J. Am. Chem. Soc., 1991, 113, 3829; D. G. Dick, R. Duchateau, J. H. Edema and S. Gambarotta, Inorg. Chem., 1993, 32, 1959; M. D. Fryzuk and H. D. Williams, Organometallics, 1983, 2, 162; H. Nöth and M. Schmidt, Organometallics, 1995, 14, 4601.

5 J. A. Jensen, J. E. Gozum, D. M. Pollina and G. S. Girolami, J. Am. Chem. Soc., 1988, 110, 1643.

6 C. Villiers and M. Ephritikhine, J. Chem. Soc., Chem. Commun., 1995, 979; K. Burgess and W. A. van der Donk, Organometallics, 1994, 13, 3616.

7 G. T. Jordan IV and S. G. Shore, Inorg. Chem., 1996, 35, 1087.

8 F.-C. Liu, J. Liu, E. A. Meyers and S. G. Shore, Inorg. Chem., 1998, 37, 3293; A. Chow, F.-C. Liu, G. Fraenkel and S. G. Shore, Magn. Reson. Chem., 1998, 36, S145.

9 F.-C. Liu, J. Liu, E. A. Meyers and S. G. Shore, Inorg. Chem., 1998, 38, 2169; F.-C. Liu, J. Liu, E. A. Meyers and S. G. Shore, J. Am. Chem. Soc., 2000, 122, 6106; E. Ding, B. Du, E. A. Meyers, S. G. Shore, M. Yousufuddin, R. Bau and G. Mclntyre, Inorg. Chem., 2005, 44, 2459.

10 E. Ding, F.-C. Liu, S. Liu, E. A. Meyers and S. G. Shore, Inorg. Chem., 2002, 41, 5329.

11 P. Paetzold, L. Geret and R. Boese, J. Organomet. Chem., 1990, 385, 1; U. Welling, P. Paetzold and U. Englert, Inorg. Chim. Acta, 1995, 231, 175; R. Shinomoto, E. Gamp, N. M. Edelstein, D. H. Templeton and A. Zalkin, Inorg. Chem., 1983, 22, 2351.

12 F.-C. Liu, J.-H. Chen, S.-C. Chen, K.-Y. Chen, G.-H. Lee and S. M. Peng, J. Organomet. Chem., 2005, 690, 291.

13 F.-C. Liu, K.-Y. Chen, J.-H. Chen, G.-H. Lee and S. M. Peng, Inorg. Chem., 2003, 42, 1758; F.-C. Liu, S.-C. Chen, G.-H. Lee and S. M. Peng, J. Organomet. Chem., 2007, 692, 2375.

14 A. G. Császár, L. Hedberg, K. Hedberg, R. C. Burns, A. T. Wen and M. J. McGlinchey, Inorg. Chem., 1991, 30, 1371; M. D. Fryzuk, M. Mylvaganam, M. J. Zaworotko and L. R. MacGillivray, J. Am. Chem. Soc., 1993, 115, 10360.

15 P. T. Wolczanski and J. E. Bercaw, Organometallics, 1982, 1, 793.

16 B. Singaram, T. E. Cole and H. C. Brown, Organometallics, 1984, 3, 774.

17 B. A. Vaartstra, J. C. Huffman, P. S. Gradeff, L. G. Hubert-Pfalzgraf, J.-C. Daran, S. Parraud, K. Yunlu and K. G. Caulton, Inorg. Chem., 1990, 29, 3126.

18 N. Edelstein, Inorg. Chem., 1981, 20, 297; E. R. Bernstein, W. C. Hamilton, T. A. Keiderling, S. J. LaPlaca, S. J. Lippard and J. J. Mayerle, Inorg. Chem., 1972, 11, 3009.

19 D. Coucouvanis, R. K. Lester, M. G. Kanatzidis and D. P. Kessissoglou, J. Am. Chem. Soc. 1985, 107, 8279; J. E. Gozum and G. S. Girolami, J. Am. Chem. Soc., 1991, 113, 3829.

20 W. A. Howard, M. T. Tina and G. Parkin, Inorg. Chem., 1995, 34, 5900.

21 J. Huheey, E. A. Keliter, and R. L. Keiter, Inorganic Chemistry, Harper Collins, New York, 4th edn, 1993, Table 8.1, p. 292.

22 R. W. Broach, I.-S. Chuang, T. J. Marks and J. M. Williams, Inorg. Chem., 1983, 22, 1081.

23 W. J. Evans, M. A. Ansari and J. W. Ziller, Inorg. Chem., 1999, 38, 1160.

24 Z. A. Starikova, E. P. Turevskaya, N. I. Kozlova, N. Y. Turova, D. V. Berdyev and A. I. Yanovsky, Polyhedron, 1999, 18, 941.

25 W. A. Howard and G. Parkin, J. Am. Chem. Soc., 1994, 116, 606.

26 M. Niehues, G. Erker, O. Meyer and R. Fröhlich, Organometallics, 2000, 19, 2813; S. Morris, M. J. Almond, C. J. Cardin, M. G. B. Drew, D. A. Rice and Y. Zubavichus, Polyhedron, 1998, 17, 2301.

27 Z. Otwinowsky and W. Minor, DENZO-SMN, Methods Enzymol., 1997, 276, 307-326.

28 R. H. Blessing, Acta Crystallogr., Sect. A: Found. Crystallogr., 1995, 51, 33; R. H. Blessing, J. Appl. Crystallogr., 1997, 30, 421-426.

29 G. M. Sheldrick, SHELXS-97, Acta Crystallogr., Sect. A: Found. Crystallogr., 1990, 46, 467.

30 G. M. Sheldrick, SHELXL-97, University of Göttingen, Göttingen, Germany, 1997. 